\title{
PENGARUH GAYA BELAJAR ANAK TERHADAP HASIL BELAJAR TEMATIK SISWA
}

\author{
Moh. Junaidi \\ Institut Agama Islam Syarifuddin Lumajang, Indonesia \\ Email: jujund96@gmail.com
}

\begin{abstract}
Abstrak
Gaya belajar anak berbeda antara satu dengan yang lain ada yang baik hasil belajar dan juga ada yang buruk yang kemungkinan ada pengaruh terhadap Hasil Belajar siswa.

Penelitian ini menggunakan jenis penelitian Studi Kasus dan metode kuantitaif. Teknik pengumpulan data menggunakan observasi, wawancara, angket, tes dll. yang dianalisis secara deskriptif dan diuji menggunakan uji manova dan anova dengan menggunakan Windows SPSS 16.0

Hasil penelitian ini menunjukkan bahwa ada pengaruh gaya belajar terhadap hasil belajar siswa. Nilai yang diperoleh peneliti pada hubungan antara gaya belajar dan hasil belajar peserta didik adalah 0,173 $\geq 0,05$. Nilai tersebut dapat di interpretasikan bahwa antara gaya belajar dan hasil belajar memiliki hasil yang tinggi. Dimana artinya, gaya belajar memiliki pengaruh yang signifikan terhadap hasil belajar peserta didik. Dengan demikian hipotesis yang diajukan diterima, yaitu terdapat pengaruh antara gaya belajar terhadap hasil belajar peserta didik kelas IVA dan IVB MI NU Habibul Abrori Suko Jogoyudan Lumajang.
\end{abstract}

Kata kunci: Pengaruh Gaya Belajar, Hasil Belajar.

\section{Pendahuluan}

Pendidikan merupakan salah satu faktor yang sangat penting dalam membangun bangsa dan negara. Dengan demikian dalam program pembangunan masalah pendidikan mendapatkan prioritas yang utama. Bangsa yang besar adalah bangsa yang mempunyai kurikulum pendidikan yang bagus dan stabil serta memberi motivasi pelajarnya agar bisa meningkatkan standar mutu pendidikan dikemudian hari. Hal tersebut sesuai dengan tujuan dan fungsi pendidikan nasional sesuai dengan UU RI No. 20 tahun 2003 tentang Sistem Pendidikan Nasional yaitu: mengembangkan kemampuan dan membentuk watak serta peradaban bangsa yang bermatabat dalam rangka mencerdaskan 
kehidupan bangsa dan bertujuan untuk mengembangkan potensi peserta didik agar menjadi manusia beriman, bertaqwa pada Tuhan YME, berakhlak mulia, sehat, cakap, kreatif, dan menjadi warga negara yang demokratis serta bertanggung jawab ${ }^{1}$.

Perkembangan zaman yang sangat pesat seperti sekarang ini sangat mempengaruhi kemajuan pendidikan. Pendidikan akan berkembang jika memperoleh dukungan dari berbagai sisi. Membicarakan tentang pendidikan yang terkait adalah nilai mendidik yang berarti, memberikan, menanamkan, menumbuhkan nilai-nilai pada peserta didik. Pendidikan berfungsi membantu peserta didik dalam pengembangan dirinya, yaitu pengembangan semua potensi, kecakapan serta karakteristik pribadinya ke arah yang positif. ${ }^{2}$

Pendidikan mempunyai peranan yang sangat penting dalam menciptakan sumber daya manusia yang berkualitas. Pendidikan merupakan kunci untuk semua kemajuan dan perkembangan yang tinggi, sehingga dengan pendidikan manusia dapat mewujudkan semua potensi dirinya menjadi individu yang berkualitas. Keberhasilan seorang siswa dalam belajar dapat dilihat dari prestasi siswa yang bersangkutan. Dalam pendidikan siswa akan dinilai keberhasilannya melalui tes hasil belajar. Hasil yang diharapkan adalah prestasi belajar yang baik karena setiap orang mengininkan prestasi yang tinggi, baik siswa, guru, sekolah, maupun orang tua hingga masyarakat. Namun antara satu siswa dengan siswa lainnya berbeda dalam pencapaian prestasi belajar.

Dalam aktivitas kehidupan manusia sehari-hari hampir tidak pernah dapat terlepas dari kegiatan belajar, baik ketika seseorang melaksanakan aktivitas sendiri, maupun didalam suatu kelompok tertentu. Dipahami atau tidak dipahami, sesungguhnya sebagian besar

\footnotetext{
${ }^{1}$ Evi Rine hartutik dkk, Undang-undang republic Indonesia nomor 20 tahun 2003 tentang system pendidikan nasional, (jogyakarta: laksana, 2012) , hlm.15

2 Nana Syaodih Sukmadinata, Landasan Psikologi Proses Pendidikan, PT. Remaja

Rosdakarya, Bandung 2005 hal : 4
} 
aktivitas didalam kehidupan sehari-hari kita merupakan kegiatan belajar. Dengan demikian dapat kita katakan, tidak ada ruang dan waktu dimana manusia dapat melepaskan dirinya dari kegiatan belajar, dan itu berarti pula bahwa belajar tidak pernah dibatasi usia, tempat maupun waktu, karena perubahan yang menuntut terjadinya aktivitas belajar itu juga tidak pernah berhenti. Menurut Plato, Aristoteles dan Thomas Aquino pendidikan adalah, belajar untuk berfikir. Oleh karena itu peserta didik harus dibiasakan untuk berfikir dengan diberi kecakapan-kecakapan dasar seperti membaca, menulis, berhitung, serta mengerjakan soal yang seperti telah dilakukan dilingkup sekolah sekarang ini. Dalam rangka mewujudkan potensi diri menjadi multi kompetensi, peserta didik harus melewati proses pendidikan yang diimplementasikan dalam proses pembelajaran. ${ }^{3}$

Pembelajaran adalah merupakan suatu proses yang membuat orang belajar. Setiap proses pembelajaran tersebut, peranan guru selaku pendidik bertugas membantu peserta didik agar dapat belajar dengan baik dan mudah. Di samping itu, peserta didik berusaha untuk mencari informasi, memecahkan masalah, dan mengemukakan pendapatnya. Pembelajaran mengandung makna adanya kegiatan belajar dan mengajar, dimana yang mengajar adalah pendidik dan yang belajar adalah peserta didik yang berorientasi pada pengembangan pengetahuan, sikap, dan keterampilan peserta didik.

Proses pembelajaran yang berkualitas dapat tercipta apabila peserta didik dan pendidik berperan aktif di dalamnya. Peserta didik dan pendidik,berinteraksi dalam suatu kegiatan yang disebut dengan pembelajaran yang berlangsung dalam proses belajar. Upaya mewujudkan proses pembelajaran yang efektif dan efisien, maka pengajar hendaknya mampu mewujudkan perilaku mengajar secara tepat, agar mampu mewujudkan perilaku belajar peserta didik melalui interaksi

${ }^{3}$ Ngainun Naim, Menjadi Guru Inspiratif, Pustaka Pelajar, Yogyakarta 2009, hal : 65 
pembelajaran yang efektif dalam proses pembelajaran yang kondusif. Menurut teori behavioristik pembelajaran adalah sebagai usaha pendidik untuk membentuk tingkah laku yang diinginkan dengan menyediakan sarana atau stimulus. Dan menurut teori humanistik, pembelajaran adalah memberi kesempatan kepada peserta didik memilih gaya belajar yang disukainya yang sesuai dengan minat dan kemampuannya. ${ }^{4}$

Berdasarkan teori yang telah disebutkan diatas maka dapat disimpulkan bahwa, salah satu usaha yang dapat dilakukan pendidik adalah merencanakan dan menggunakan gaya belajar menyenangkan,yang dapat mengkondisikan peserta didik agar dapat terciptanya suasana belajar yang efektif yang sesuai dengan minat peserta didik, serta memberikan stimulus dan sarana untuk menunjang proses belajar.

Cara belajar yang dimiliki siswa sering disebut dengan gaya belajar atau modalitas belajar siswa. Gaya belajar merupakan suatu kombinasi dari bagaimana siswa menyerap pelajaran, dan kemudian mengatur serta mengubah informasi yang telah didapat. Terdapat tiga gaya belajar seseorang yaitu visual (Cenderung belajar melalui apa yang mereka lihat), audiotutial (belajar melalui apa yang mereka dengar), dan kinestetik (belajar melalui gerak dan sentuhan). ${ }^{5}$ Meskipun gaya belajar yang dimiliki berbeda-beda, namun tujuan yang hendak dicapai tetap sama yaitu guna mencapai tujuan pembelajaran dan mencapai prestasi belajar yang diharapkan. Ada siswa yang mampu mamaksimalkan gaya belajarnya, ada juga siswa yang belum mampu mamaksimalkangaya belajarnya karena mereka belum menyadari gaya belajar yang mereka miliki. Hal tersebut terbukti dari masih adanya siswa yang menyibukkan diri sewaktu guru menjelaskan pelajaran.

${ }^{4}$ Annurahman, Belajar dan Pembelajaran, Alfabeta, Bandung 2010, hal : 89

${ }^{5}$ Bobbi DePorter, Quantum Learning (New York, 1992), hlm.110 
Berdasarkan pengamatan sekilas yang peneliti lakukan di MI Habibul Abrori suko Jogoyudan Lumajang bahwasanya peneliti menemukan berbagai anak mengalami kesulitan dalam menangkap pelajaran yang diberikan oleh seorang guru yang pada akhirnya akan berdampak pada hasil belajar peserta didik. Dan juga siswa sering kesulit untuk menyesuaikan diri terhadap gaya pembelajaran yang dilakukan oleh guru di sekolah. Demikian juga dirumah murid sering kesulitan karena gaya belajar yang telah ditetapkan oleh orang tua dirumah. ${ }^{6}$

Sebelum digunakan dalam penelitian angket dan tes di uji ke validan dan reabilitasnya. Uji coba instrumen ini, perlu dilakukan oleh peneliti sebelum melakukan penelitian. Hal ini dimaksudkan agar instrumen yang digunakan dalam mengukur variabel memiliki validitas dan reabilitas sesuai dengan ketentuan. Instrumen dikatakan valid apabila instrumen tersebut telah lolos uji reabilitasnya.

Berdasarkan data dari wawancara peneliti yang peneliti lalukukan sebelum melaksanakan penelitian dan lihat permasalahan apa yang sekiranya anak yang sekarang dia hadapi. Peneliti mencoba iseng bertanya kepada beberapa murid bahwa mereka mengeluhkan dengan gaya mengejar yang dilakukan guru terlalu monoton ada juga yang senang dan ada juga lebih senang ketika guru itu langsung praktek daripada teori melulu, dan juga ada yang senang dengan melihat gambar atau contoh yang nyata, dengan begitu kata mereka dapat cepat faham apa yang disampaikan guru kepadanya.dan juga peneliti bertanya kepada murid yang nilainya banyak merahnya.

Menurut peserta didik mengatakan bahwa mereka kalo belajar lebih seneng kalau langsung praktek dan ada juga nilainya bagus mereka mengatakan bahwa saya lebih senang dengan melihat gambar atau dengan guru menerangkan pun saya paham dengan apa yang disampaikannya.

\footnotetext{
6 Penelitian sekilas, MI NU Habibul Abrori Suko Jogoyudan Lumajang, 31 Januari 2018
} 
Melalui bermain, anak juga berkesempatan untuk mengembangkan kemampuan nalarnya, karena melalui permainan serta alat-alat permainan anak-anak belajar mengerti dan memahami suatu gejala tertentu. Kegiatan ini sendiri merupakan suatu proses dinamis di mana seorang anak memperoleh informasi dan pengetahuan yang kelak dijadikan landasar dasar pengetahuannya dalam proses belajar berikutnya di kemudian hari.. ${ }^{7}$

\section{Pembahasan}

\section{Gaya Belajar Siswa}

Berdasarkan data wawancara yang telah dilakukan oleh peneliti dengan guru mata pelajaran tematik kelas IV A dan IV B di MI NU Habibul Abrori Suko jogoyudan Lumajang yang pertama dengan menggunakan wawancara peneliti dengan guru kelas IV A yang mengajar mata pelajaran tematik yang pertama dengan bapak Khoirus Shohib selaku guru mata pelajaran tematik kelas IV A.

Beliau menjelaskan bahwasanya di dalam kelas IV A terdapat berbagai macam gaya belajar tiap anak berbeda-beda cara menangkap informasinya, dan gaya belajarnya ada yang kinestetik ada yang audio dan juga ada yang audio dan ada visual dan juga ada yang audio visual.

Menurutnya bahwasanya gaya belajar sangat berpengaruh terhadap hasil belajar. Karena dalam menentukan hasil belajar kita menggunakan tes dan apabila seorang siswa itu dalam suatu proses pembelajaran dan proses penangkapan informasi ada yang cepat dan ada yang lambat. Apabila seorang siswa ini penengkapan atau cara berfikirnya atau responnya cepat maka hasil belajarnya akan sangat bagus begitu pun sebaliknya.

Setelah peneliti wawancara dengan guru Mata Pelajaran tematik pada kelas IV A dan selanjutnya peneliti wawancara kepada guru wali kelas IV B.

${ }^{7}$ Bobbi, Quantum Learning,hlm.110 
Menurut guru mata pelajaran tematik kelas IV B didalam kelas IV B juga sangat bermacam- macam ada yang kinestetik ada juga yang audio, visual, dan audio visual. Menurutnya dalam setiap proses pembelajaran penangkapan informasi anak berbeda-beda ada yang langsung cepat tangg[p ada juga yang lama dalam menanggapinya, dan dari segi ini gaya belajar sangat memepengaruhi hasil belajarnya.

Hasil belajar didapat diketahui melalui tes yang dilaksananakan guru, maka dari itu guru kelas IV B mengatakan bahwa gaya belajar sangat mempengaruhi hasil belajar siswa.

Setelah itu peneliti menggunakan metode observasi berikut data yang diddapat oleh peneliti dalam observasi, dalam opservasi peneliti mendapatkan data bahwasanya dikelas IV A terdapat berbagai macam gaya belajar. Diantaranya yaitu kinestetik, audio dan audio visual. Dalam hal ini peneliti juga menemukan bahwa gaya belajar berpengaruh terhadap hasil bel;ajar, karena anak yang audio audio, visual dan anak kinestetik sangat berbeda jauh hasil belajaranya. Dalam pengamatan peneliti gaya belajar anak kelas IV A dab IV B tidak jauh berbeda.

Setelah itu peneliti menggunakan metode observasi dari dat yang peneliti dapatkan dapan peneliti ketahui bahwa anak yang kinestetik nilainya lebih rendah dari anak yang audio dan audio visual.

Tujuan penelitain ini adalah untuk mengetahui pengaruh gaya belajar terhadap hasil belajar peserta didik MI Ma'arif NU Habibul Abrori dalam belajar tematik. Penelitian ini mengambil populasi peserta didik kelas IV sebanyak 44 anak.

Data dalam penelitian ini diperoleh melalui beberapa metode, yaitu metode tes, metode angket, metode wawancara, metode observasi, dan metode dokumentasi.

Metode wawancara digunakan untuk mnegetahui gaya belajar anak didik kelas IV A atau IV B berikut data wawancara yang diperoleh 
peneliti dari wawancara dari guru mata pelajaran tematik kelas IV A sebagai berikut :

Pada kelas IV A yang didalamnya terdapat 22 siswa, guru yang mengampu mata pelajaran tematik bernama Bapak Khoirus Shohib, S.Ag. Dalam kelas IV A ini semua muridnya sama rata jadi tidak ada perbedaan antara kelas IV A dan B apakah yang A pintar-pintar dan B tidak begitu pintar, tidak ada perbedaanya dalam kelas iv $\mathrm{A}$ ini sumua sama rata.

Pada kelas IV A yang tidak begitu pintar,anak yang tidak bnegitu pintar kalo di dalam kelas apabila dicampur dengan anak bisa tidak menganggangu anak yang bisa, melainkan anak yang bisa itu mengajari yang kurang bisa manangkap pelajaran dengan cepat. Dalam kelas IV A ini sudah menggunakan kurikulum 2013 jadi sudah menggunakan pem,belajaran pertema yaitu tematik.

Pembelajaran tematik ini snagat mempermudah guruh dalam melaksanakan proses pembelajaran karena dalam pembeljaran tematik ini beberapa mata pelajaran dijadikan satu. Dan dalam tematik ini proses pemebelajrannya sangat menguntungkan gura dalam prosesnya anak lebih banyak praktek dan juga anak lebih kreatif dan juga aktif anak juga lebih cepat faham dengan materi apa yang diberikan guru dalam suatu pembalajaran.

Pada kelas IV A terdapat beberapa gaya pembejaran, menurut bapak shohib adalah sangat bervariasi. Menurutnya ada Ada anak yang kalo hanya mendengarkan saja dia sudah menangkap. Ada yang dengan melihat gambar dia baru paham. Ada jugan dengan dua-duanya tidak bisa menangkap, tapi dengan praktek baru dia bisa paham dan mengerti tantang apa yang mereka pelajari.

Guru mata pelajaran tematik ini punya trik atau dapat mensiasati dalam menangani berbagai macam gaya belajar peserta didiknya. menurutnya di tematik ini semua itu terangakum dalam satu metode, dengan melaksanakan pemebeljaran tematik ini semua bisa dilakukan 
kayak, yang hanya mendengar bisa paham, guru hanya menjelaskan dengan metode cerama, anak yang pahamnya dengan melihat ditematik banyak contoh dengan gambar gambar dan yang langsung praktek ditematik juga anak disruh langsung praktek dan guru membawah contoh yang nyata atau dapat digunakan dengan memaparkan video dengan layar proyektor.

Hasil belajar yang diperoleh dikelas IV A ini yang memiliki beberapa macam pembelajaran hasil belajarnya sangat baik nilainya terkadang ada anak yang gaya belajarnya langsung praktek terkadang agak sedikit dikit dibawah yang hanya dengan melihat dan mendengarkan, karena anak ini tidak bisa diam dalam proses pembelajaran. umek, ae. Jadi terkadang apa yang disampaikan guru kurang dia pahami. Jadi tergantung dari gaya belajar anak tersebut. Begitulah data yang peniliti dapatkan dari wawancara peniliti dengan Guru mata pelajaran Tematik.

Berikut data wawancara dengan guru mata pelajaran tematik kelas IV B sebagai berikut :

Pada kelas IV B MI NU Habibul Abrori Suko Jogoyudan Lumajang terdapat 22 siswa siswa berarti sama dengan kelas IV A. Guru mata pelajaran tematik bernama Ibu Fiqri Lailiya, S.Pd. Keadaan kelas saata proses pembelajaran berlangsung dengan lancar, aman, tertib dan sangat kondusif dan berlansung dengan lancar, tapi terkadang ada anak yang sering mrngganggu saat pemebelajaran berlangsung.

Terkadang terdapat salah seorang siswa yang tidak bisa diam dia selalu bergerak walau pun saya suruh diam, diam Cuma sebentar habis itu berulah lagi itu disaat saya menerangkan mas, tapi kalo dengan praktek dia seneng mas sangat aktif dan mudah mengerti. Menurut guru mata pelajaran tematik iya terkadang saya terganggu, tapi ya mau gimana lagi saya berusaha sekuat dan semaksimal mungkin.

Gaya belajar dilas IV B menurut guru mata pelajaran tematik di IV B itu ssanagat banyak mas dan bervariasi nama juga manusia itu kan 
berbeda beda ya mas?, dari segi penangkapan informasi ada yang yang lambat dan ada yang sedang atau pun yang cepat. kalo yang lambat itu, dia menangkap pelajarannya susah atau lama mengerti atau ndak ngerti ngerti, masio diterangno kyok opo pancet ae ndak ngerti-ngerti. kalo yang seedang itu biasaanya setelah diterangkan melalui teori masih belum paham, tapi kalo sudah di kasih contoh, kyak gambar atau video atau contoh nyata itu baru mengerti. kalo yang cepat itu ya setelah diterangkan teori dia cepat faham apalagi di kasih contoh dia lebih tambah paham.

Pada kelas IV B juga menggunakan pembelajaran tematik. Menurut guru kelas IV B , pembelajaran tematik itu sangat membantu guru saat pembelajaran dan dari pembejaran tematik ini gaya belajar yang bervariasi ini bisa dapat memahami semua. Bahkan anak yang biasanya tidak bisa sama sekalih sedikit agak bisa karena ada contoh gambar.

Menurut bu Fiqri selaku guru mata pelajaran te,matik bahwasanya gaya belajar juga mempengaruhi hasil belajar seorang peserta didik. karena gaya belajar sangat mempengaruhi karena dari mulai cara yang dapat faham dengan gaya audio, atau mendengarkan, ada yang visual atau hanya dengan melihatnya dia baru dia faham, atau dengan langsung yang praktek baru dia mengerti. Itu kan ya mempengaruhi pemehaman anak mas, dan waktu diujian itulah terlihat mas bahwa gaya belajar sangat mempengaruhi hasil belajarnya. Cara untuk mengatasi permasalahan yang sering timbul dan dalam proses pembelajaran berlansung menurut bu fiqri, untuk mengatasi itu semua untuk sangat ini saya juga mencoba beberapa model-model pembelajaran yang saya terapkan mas, jadi tiodak monoton cerama terus, dan hasil alhamdulillah agak sedikit membaik mas. Begitulah data yang didapatkan peneliti yang menggunakan metode wawancara dengan ibu laliyatul fiqriyah, S. Pd.

Metode observasi digunakan untuk mengamati keadaan sekolah, meliputi sarana, dan proses pembelajaran. berikut data yang didapatkan peneliti sebagai berikut : Pada kelas IV A teerdapat beberapa macam - 
macam gaya belajara yang dimiliki peserta didik kelas IV A. Mulai dari anak yang yang audio, anak ini cenderung diam dan mendengarkan apa yang disamapaikan oleh guru, terkadang dia sambil mengantuk-ngantuk mendengarkan pemebelajaran akan tetapi anehnya, sang anak ini ketika ditunjuk dan diberi pertanyaan oleh oleh dia bisa menjawab dengan tepat dan benar. Dan hasil belajarnya juga relatif baik.

Ada anak yang audio visual dia dalam pembeljaran ber;langsung dia selalu fokus dalam mendengarkan apa yang disampaikan oleh seorang tentang materiu yang diajarkan dia juga memerhatikan gerakan guru dan juga dia sangat senang ketika dikasih contoh dengan gambargambar atau contoh dengan gambar yang nyata. Dan hasil belajarnya ini sangat baik dan cepat merespon apa yang di sampaikan guru.

Ada anak yang yang tridak bisa diam walaupun 1 menit yaitu anak yang memiliki gaya be.lajar kinestetik. Anak ini tidak bisa anggota badannya harus bergerak dan juga anak yang seperti ini sering mengganggu anak yang audio visual anak ini sangat senang waktu pelajaran langsung pada praktek, seperti mata pelajaran pendidikan jasmani dan rohaniu dan kesenian. Anak ini selalu aktif dan juga sanagat senang ketika pembelajaran langsung praktek. Dan hasil pemebeljarannya sangat bagus ketika pemeblajaran seperti itu, begitu pun dengan pembelajaran yang langsung praktek lainnya akan tetapi tidak pada pemeblajaran yang hanya mendengarkan teori cenderung nilainya rendah dari yang langsung praktek.

Data diatas adalah data yang saya peroleh dari guru mata pelajaran tematik dari kelas IV A dan IV B. Dari data diatas peneliti bisa mengetahui anak yang nilainya sedikit rendah dari yang lain berarti anak kinestetik Metode tes digunakan untuk mengetahui pengaruh gaya belajar terhadap hasil belajar tematik. sedangkan metode dokumentasi digunakan peneliti untuk memperoleh data-data dari sekolah. 
Berkaitan dengan metode angket,dalam metode ini terdapat 20 pertanyaan yang sesuai dengan kegiatan peserta didik dan dalam tes terdapat 10 butir soal multipel chois tetang materi yang terkandung dalam buku tematik tema 7 yang mana telah diuji tingkat validitasnya.

Dari hasil uji validitas dan rehabilitas terhadap butrir-butir kuisioner ini. Peneliti peneliti mendapatkan hasil sebagai berikut :

Uji Validitas dan Reabilitas Tes

Uji validitas akan menguji masing-masing variabel yang digunakan dalam penelitian ini, dimana keseluruhan variabel penelitian memuat pernyataan yang harus dijawab oleh responden. Uji validitas dilakukan dengan membandingkan nilai $r$ hitung dengan $r$ tabel untuk tingkat signifikansi $5 \%$. Jika $r$ hitung $>\mathrm{r}$ tabel maka pernyataan atau indikator tersebut dinyatakan valid, begitu juga sebaliknya bila $r$ hitung $<r$ tabel maka pernyataan atau indikator tersebut dinyatakan tidak valid.

Tabel 4.3

\section{Reliability Statistics}

\begin{tabular}{|c|c|}
\hline $\begin{array}{c}\text { Cronbach's } \\
\text { Alpha }\end{array}$ & $\begin{array}{c}\mathrm{N} \text { of } \\
\text { Items }\end{array}$ \\
\hline .776 & 11 \\
\hline
\end{tabular}

Berdasarakan tabel 4.3 diketahui bahwa hasil perhitungan ini reliabel, karena rhitung $\geq$ rtabel. Nilai rtabel dapat dilihat pada (lampiran ..) sehingga butir kuisioner ini dapat digunakan sebagai penelitian.

Uji Validitas dan Reabilitas Angket Gaya Belajar

Setelah melakukan validitas dan reabilitas pada tes, peneliti menguji validitas dan reabilitas pada angket gaya belajar. Uji ini digunakan untuk melihat, kelayakan angket yang digunakan sebelum melakukan penelitian. Agar data yang didapatkan oleh peneliti dapat digunakan sebagai perbandingan. Uji validitas akan menguji masing-masing variabel yang digunakan dalam penelitian ini, dimana keseluruhan variabel 
penelitian memuat pernyataan yang harus dijawab oleh responden. Uji validitas dilakukan dengan membandingkan nilai $r$ hitung dengan $r$ tabel untuk tingkat signifikansi $5 \%$. Jika $\mathrm{r}$ hitung $>\mathrm{r}$ tabel maka pernyataan atau indikator tersebut dinyatakan valid, begitu juga sebaliknya bila $\mathrm{r}$ hitung $<\mathrm{r}$ tabel maka pernyataan atau indikator tersebut dinyatakan tidak valid.

Tabel 4.4

\section{Reliability Statistics}

\begin{tabular}{|c|c|}
\hline $\begin{array}{c}\text { Cronbach's } \\
\text { Alpha }\end{array}$ & $\begin{array}{c}\text { N of } \\
\text { Items }\end{array}$ \\
\hline .949 & 20 \\
\hline
\end{tabular}

Berdarkan tabel 4.4 menghasilkan bahwa angket gaya belajar dapat dinyatakan reliabel.

Analisis Data dan Uji Hipotesis

Setelah data terkumpul langkah selanjutya adalah melakukan analisis pada data tersebut untuk memperoleh hasil dari penelitian. Analisis data yang digunakan dalam penelitian ini adalah uji beda, yaitu menggunakan uji MANOVA. Sebelum melakukan uji MANOVA terdapat uji prasyarat yaitu dengan menguji homogenitas varian dan homogenitas covarian.

Uji Homogenitas Varian

Uji homogenitas ini dimaksud untuk mengetahui, apakah data yang diperoleh dari kelas kontrol dan eksperimen mempunyai varian yang sama atau berbeda. Data yang digunakan untuk melakukan uji homogenitas adalah data yang berasal dari tes pada kedua kelas tersebut. Dalam uji ini hasil yang diperoleh dapat dikatakan mempunyai varian yang sama jika nilai signifikan $\geq 0,05$, dan dapat dikatakan berbeda jika nilai signifikan $\leq 0,05$. Uji homogenitas varian dalam penelitian ini menggunakan SPSS 16. 0 for Windows 


\section{Uji Homogenitas Covarian}

Uji homogenitas covarian digunakan untuk melihat sejauh mana dua variabel yang berkaitan atau bagaimana mereka bervariasi bersama. Suatu distribusi dikatakan homogen jika taraf signifikan $\geq 0,05$ dan suatu distribusi dikatakan tidak homogen jika taraf signifikan $\leq 0,05$. Uji homogenitas covarian ini dalam penelitian ini menggunakan SPSS 16. 0 for Windows

Uji Hipotesis

Dari hasil perhitungan yang dicantumkan pada penjelasan di atas, menunjukkan bahwa masing-masing variabel dalam penelitian tersebut memenuhi persyaratan kelayakan untuk dapat diujikan lebih lanjut seperti pada pembahasan berikut ini : 1) Uji Homogenitas Varian Uji homogenitas varian dari data penelitian ini dilihat dari hasil uji Levene yang dicantumkan oleh tabel sebagai berikut :

Tabel 4.5

\section{Test of Homogeneity of Variances}

Hasil Belajar

\begin{tabular}{|c|c|c|c|}
\hline $\begin{array}{c}\text { Levene } \\
\text { Statistic }\end{array}$ & df1 & df2 & Sig. \\
\hline 1.568 & 6 & 32 & .189 \\
\hline
\end{tabular}

Menurut tabel 4.5 hasil uji Levene output SPSS diatas menunjukkan bahwa nilai signifikan variabel Hasil Belajar (Y) berdasarkan variabel Gaya Belajar $(X)=0,189 \geq 0,05$ artinya data variabel Hasil Belajar (Y) berdasarkan variabel Gaya Belajar (X) mempunya Varian yang sama. Artinya, baik angket maupun tes soal memiliki varian yang homogen, sehingga MANOVA bisa dilanjutkan.

Uji Homogenitas Covarian.

MANOVA mempersyaratkan bahwa matriks varian/covarian dari variabel dependen sama.Uji homogenitas matriks varian/covarian dilihat dari hasil uji Box"es M. Apabila nilai Box"es M signifikan maka hipotesis nol 
yang menyatakan bahwa matriks varian/covarian dari variabel dependen sama ditolak. Dalam kondisi ini analisis MANOVA tidak dapat dilanjutkan. Namun Hasil uji Box"es M dengan SPSS pada penelitian ini tampak pada tabel berikut:

Tabel 4.6

$\begin{gathered}\text { Box's Test of Equality } \\
\text { of Covariance } \\
\text { Matrices }^{\text {a }}\end{gathered}$
\begin{tabular}{|c|c|}
\hline Box's M & 6.412 \\
F & .447 \\
df1 & 12 \\
df2 & $1.418 \mathrm{E} 3$ \\
Sig. & .945 \\
\hline
\end{tabular}

Menurut tabel 4.6 diatas nilai Box"s $\mathrm{M}=6.412$ dengan signifikansi 0,945. Apabila ditetapkan taraf signifikansi penelitian 0,05, maka harga Box"s M yang diperoleh tidak signifikan karena signifikansi yang diperoleh 0,945 lebih besar dari 0,05. Dengan demikian hipotesis nol diterima. Berarti matriks varian/covarian dari variabel dependen sama, sehingga analisis MANOVA dapat dilanjutkan.

Setelah kedua uji persyaratan hipotesis dipenuhi dilanjutkan dengan uji hipotesis MANOVA. Uji MANOVA digunakan untuk menguji apakah terdapat perbedaan beberapa variabel terikat antara beberapa kelompok yang berbeda. Dalam contoh ini dibedakan dengan menganalisis adanya pengaruh gaya belajar terhadap hasil belajar. Keputusan diambil dengan analisis Pillae Trace, Wilk Lambda, Hotelling Trace, Roy's Largest Root.

Jika hasil analisis menunjukkan bahwa harga F memiliki signifikansi yang lebih besar dari 0,05 (lampiran 17). Artinya, harga F untuk Pillae Trace, Wilk Lambda, Hotelling Trace, Roy's Largest Root semuanya signifikan. Jadi, terdapat perbedaan antara peserta didik yang diajar 
dengan gaya belajar audio (A1), gaya belajar visual (A2), dan gaya belajar kinestetik (A3).

Uji MANOVA Gaya Belajar Terhadap Hasil Belaja Uji MANOVA Gaya Belajar Terhadap Hasil Belajar dilihat dari hasil nilai hasil tes yang diberikan kepada peserta didik. Dengan syarat MANOVA yaitu taraf signifikan .

Tabel 4.7

Tests of Between-Subjects Effects

\begin{tabular}{|c|c|c|c|c|c|c|c|c|}
\hline Source & $\begin{array}{c}\text { Depend } \\
\text { ent } \\
\text { Variable }\end{array}$ & $\begin{array}{l}\text { Type III } \\
\text { Sum of } \\
\text { Squares }\end{array}$ & Df & $\begin{array}{l}\text { Mean } \\
\text { Square }\end{array}$ & $\mathrm{F}$ & Sig. & $\begin{array}{l}\text { Noncent. } \\
\text { Parameter }\end{array}$ & $\begin{array}{l}\text { Observed } \\
\text { Powerb }^{b}\end{array}$ \\
\hline \multirow{2}{*}{$\begin{array}{c}\text { Corrected } \\
\text { Model }\end{array}$} & Angket & $168.304^{a}$ & 5 & 33.661 & .623 & .683 & 3.113 & .203 \\
\hline & Tes & $366.082^{c}$ & 5 & 73.216 & 1.639 & .173 & 8.197 & .508 \\
\hline \multirow{2}{*}{ Intercept } & Angket & $\begin{array}{c}147892.7 \\
78\end{array}$ & 1 & $\begin{array}{c}147892.7 \\
78\end{array}$ & 2.735E3 & .000 & 2735.192 & 1.000 \\
\hline & Tes & \begin{tabular}{|c|}
155648.7 \\
15 \\
\end{tabular} & 1 & \begin{tabular}{|c|}
155648.7 \\
15 \\
\end{tabular} & 3.485E3 & .000 & 3485.152 & 1.000 \\
\hline \multirow{2}{*}{ Kelas } & Angket & 168.304 & 5 & 33.661 & .623 & .683 & 3.113 & .203 \\
\hline & Tes & 366.082 & 5 & 73.216 & 1.639 & .173 & 8.197 & .508 \\
\hline \multirow{2}{*}{ Error } & Angket & 2054.673 & 38 & 54.070 & & & & \\
\hline & Tes & 1697.100 & 38 & 44.661 & & & & \\
\hline \multirow{2}{*}{ Total } & Angket & $\begin{array}{c}224169.0 \\
00\end{array}$ & 44 & & & & & \\
\hline & Tes & \begin{tabular}{|c|}
242120.0 \\
00 \\
\end{tabular} & 44 & & & & & \\
\hline \multirow{2}{*}{$\begin{array}{c}\text { Corrected } \\
\text { Total }\end{array}$} & Angket & 2222.977 & 43 & & & & & \\
\hline & Tes & 2063.182 & 43 & & & & & \\
\hline
\end{tabular}

a. $\mathrm{R}$ Squared $=, 076$ (Adjusted $\mathrm{R}$ Squared $=-, 046)$

b. Computed using alpha $=, 05$

c. $\mathrm{R}$ Squared $=, 177$ (Adjusted $\mathrm{R}$

Squared $=, 069$ ) 
Berdasarkan dengan tebel 4.7, dengan hasil data yang diperoleh yaitu $0,173 \geq 0,05$ maka menurut kaidah MANOVA jika taraf signifikan lebioh besar dari 0,05. Maka adanya pengaruh yang signifikan gaya belajar terhadap hasil belajar peserta didik MI NU Habibul Abrori Suko Jogoyudan Lumajang dalam belajar tematik tema 7 dari data tabel diatas bahwanya gaya belajar audio visual sangat berperngaruh besar terhadap hasil belajar anak dari angket yang telah disebarkan bahwa anak yang memiliki gaya belajar audiovisual nilainya baik yaitu $0,683 \geq 0,05$.

Seberapa besar pengaruh gaya belajar siswa terhadap hasil belajar Tematik siswa kelas 4 di MI Habibul Abrori Suko Jogoyudan Lumajang?

Berdasarkan data hasil yang diperoleh peneliti dari uji validasi dan reabilitas soal tes.

Tabel 4.8

Reliability Statistics

\begin{tabular}{|c|c|}
\hline $\begin{array}{c}\text { Cronbach's } \\
\text { Alpha }\end{array}$ & $\begin{array}{c}\text { N of } \\
\text { Items }\end{array}$ \\
\hline .776 & 11 \\
\hline
\end{tabular}

Berdasarakan tabel 4.8 diketahui bahwa hasil perhitungan ini reliabel, karena rhitung $\geq$ rtabel. Nilai rtabel sehingga butir kuisioner ini dapat digunakan sebagai penelitian. Selanjutnya peneliti menguji angket gaya belajar dengan menggunanakan Windowws SPSS 16.0

Tabel 4.9

\section{Reliability Statistics}

\begin{tabular}{|c|c|}
\hline $\begin{array}{c}\text { Cronbach's } \\
\text { Alpha }\end{array}$ & $\begin{array}{c}\text { N of } \\
\text { Items }\end{array}$ \\
\hline .949 & 20 \\
\hline
\end{tabular}

Berdasarakan tabel 4.9 diketahui bahwa hasil perhitungan ini reliabel, karena rhitung $\geq$ rtabel. Nilai rtabel sehingga angket katakan layak untuk digunakan untuk mengetahui gaya belajar anak. Setelah 
melakukan validasi angket dan soal tes selanjutnya peneliti melakukan penelitian dan menggunakan metode tes dan angket.

Setelah data terkumpul langkah selanjutya adalah melakukan analisis pada data tersebut untuk memperoleh hasil dari penelitian. Analisis data yang digunakan dalam penelitian ini adalah uji beda, yaitu menggunakan uji MANOVA. Sebelum melakukan uji MANOVA terdapat uji prasyarat yaitu dengan menguji homogenitas varian dan homogenitas covarian. Dan Uji homogenitas ini dimaksud untuk mengetahui, apakah data yang diperoleh dari kelas kontrol dan eksperimen mempunyai varian yang sama atau berbeda. Data yang digunakan untuk melakukan uji homogenitas adalah data yang berasal dari tes pada kedua kelas tersebut. Dalam uji ini hasil yang diperoleh dapat dikatakan mempunyai varian yang sama jika nilai signifikan $\geq 0,05$, dan dapat dikatakan berbeda jika nilai signifikan $\leq 0,05$. Uji homogenitas varian dalam penelitian ini menggunakan SPSS 16. 0 for Windows.

Setelah itu peneliti melakukan uji homogenitas covarian digunakan untuk melihat sejauh mana dua variabel yang berkaitan atau bagaimana mereka bervariasi bersama. Suatu distribusi dikatakan homogen jika taraf signifikan $\geq 0,05$ dan suatu distribusi dikatakan tidak homogen jika taraf signifikan $\leq 0,05$. Uji homogenitas covarian ini dalam penelitian ini menggunakan SPSS 16. 0 for Windows

Setelah uji homogen dilanjutkan dengan menggunakan uji hipotesis dari hasil perhitungan yang dicantumkan pada penjelasan di atas, menunjukkan bahwa masing-masing variabel dalam penelitian tersebut memenuhi persyaratan kelayakan untuk dapat diujikan Uji homogenitas varian dari data penelitian ini dilihat dari hasil uji Levene yang dicantumkan oleh tabel sebagai berikut : 
Tabel 4.10

\section{Test of Homogeneity of Variances}

Hasil Belajar

\begin{tabular}{|c|c|c|c|}
\hline $\begin{array}{c}\text { Levene } \\
\text { Statistic }\end{array}$ & df1 & df2 & Sig. \\
\hline 1.568 & 6 & 32 & .189 \\
\hline
\end{tabular}

Menurut tabel 4.10 hasil uji Levene output SPSS diatas menunjukkan bahwa nilai signifikan variabel Hasil Belajar (Y) berdasarkan variabel Gaya Belajar $(X)=0,189 \geq 0,05$ artinya data variabel Hasil Belajar (Y) berdasarkan variabel Gaya Belajar (X) mempunya Varian yang sama. Artinya, baik angket maupun tes soal memiliki varian yang homogen, sehingga MANOVA bisa dilanjutkan.uji homogen convarian MANOVA mempersyaratkan bahwa matriks varian/covarian dari variabel dependen sama.Uji homogenitas matriks varian/covarian dilihat dari hasil uji Box"s M. Apabila nilai Box"s M signifikan maka hipotesis nol yang menyatakan bahwa matriks varian/covarian dari variabel dependen sama ditolak. Dalam kondisi ini analisis MANOVA tidak dapat dilanjutkan. Namun Hasil uji Box"s M dengan SPSS pada penelitian ini tampak yang telah didpaparkan dalam tabel diatas.

Tabel diatas nilai Box"s $\mathrm{M}=6.412$ dengan signifikansi 0,945. Apabila ditetapkan taraf signifikansi penelitian 0,05, maka harga Box"s M yang diperoleh tidak signifikan karena signifikansi yang diperoleh 0,945 lebih besar dari 0,05. Dengan demikian hipotesis nol diterima. Berarti matriks varian/covarian dari variabel dependen sama, sehingga analisis MANOVA dapat dilanjutkan.

Setelah kedua uji persyaratan hipotesis dipenuhi dilanjutkan dengan uji hipotesis MANOVA. Uji MANOVA digunakan untuk menguji apakah terdapat perbedaan beberapa variabel terikat antara beberapa kelompok yang berbeda. Dalam contoh ini dibedakan dengan menganalisis adanya 
pengaruh gaya belajar terhadap hasil belajar. Keputusan diambil dengan analisis Pillae Trace, Wilk Lambda, Hotelling Trace, Roy's Largest Root.

Jika hasil analisis menunjukkan bahwa harga F memiliki signifikansi yang lebih besar dari 0,05 (lampiran 17). Artinya, harga F untuk Pillae Trace, Wilk Lambda, Hotelling Trace, Roy's Largest Root semuanya signifikan. Jadi, terdapat perbedaan antara peserta didik yang diajar dengan gaya belajar audio (A1), gaya belajar visual (A2), dan gaya belajar kinestetik (A3). Setelah itu baru dilanjutkan dengan Uji MANOVA Gaya Belajar Terhadap Hasil Belajar.

Tests of Between-Subjects Effects

\begin{tabular}{|c|c|c|c|c|c|c|c|c|}
\hline Source & $\begin{array}{c}\text { Depend } \\
\text { ent } \\
\text { Variable }\end{array}$ & \begin{tabular}{|l|} 
Type III \\
Sum of \\
Squares
\end{tabular} & Df & $\begin{array}{l}\text { Mean } \\
\text { Square }\end{array}$ & $\mathrm{F}$ & Sig. & $\begin{array}{l}\text { Noncent. } \\
\text { Parameter }\end{array}$ & $\begin{array}{c}\text { Observed } \\
\text { Power }^{\mathrm{b}}\end{array}$ \\
\hline \multirow{2}{*}{$\begin{array}{c}\text { Corrected } \\
\text { Model }\end{array}$} & Angket & $168.304^{a}$ & 5 & 33.661 & .623 & 683 & 3.113 & .203 \\
\hline & Tes & $366.082^{c}$ & 5 & 73.216 & 1.639 & .173 & 8.197 & .508 \\
\hline \multirow{2}{*}{ Intercept } & Angket & \begin{tabular}{|c|}
147892.7 \\
78
\end{tabular} & 1 & $\begin{array}{c}147892.7 \\
78\end{array}$ & 2.735E3 & .000 & 2735.192 & 1.000 \\
\hline & Tes & $\begin{array}{c}155648.7 \\
15\end{array}$ & 1 & $\begin{array}{c}155648.7 \\
15\end{array}$ & 3.485E3 & .000 & 3485.152 & 1.000 \\
\hline \multirow{2}{*}{ Kelas } & Angket & 168.304 & 5 & 33.661 & .623 & .683 & 3.113 & .203 \\
\hline & Tes & 366.082 & 5 & 73.216 & 1.639 & .173 & 8.197 & .508 \\
\hline \multirow{2}{*}{ Error } & Angket & 2054.673 & 38 & 54.070 & & & & \\
\hline & Tes & 1697.100 & 38 & 44.661 & & & & \\
\hline \multirow{2}{*}{ Total } & Angket & \begin{tabular}{|c|}
224169.0 \\
00
\end{tabular} & 44 & & & & & \\
\hline & Tes & $\begin{array}{c}242120.0 \\
00\end{array}$ & 44 & & & & & \\
\hline \multirow{2}{*}{$\begin{array}{c}\text { Corrected } \\
\text { Total }\end{array}$} & Angket & 2222.977 & 43 & & & & & \\
\hline & Tes & 2063.182 & 43 & & & & & \\
\hline
\end{tabular}

a. $\mathrm{R}$ Squared $=, 076$ (Adjusted $\mathrm{R}$

Squared $=-, 046)$

b. Computed using alpha $=, 05$ 
c. $\mathrm{R}$ Squared $=, 177$ (Adjusted $\mathrm{R}$

Squared $=, 069$ )

\section{Penutup}

Berdasarkan hasil penelitian yang dilaksanakan di MI NU Habibul Abrori Suko Jogoyudan Lumajang tentang pengaruh gaya belajar terhadap hasil belajar peserta didik. Dapat diambil kesimpulan bahwa ada pengaruh yang signifikan, gaya belajar terhadap hasil belajar peserta didik dalam belajar tematik tema 7 berdasarkan nilai taraf signifikan 0,173 $\geq$ 0,05 .

\section{Daftar Pustaka}

hartutik Evi Rine, dkk 2012, Undang-undang republic Indonesia nomor 20 tahun 2003 tentang system pendidikan nasional, Jogyakarta; laksana.

Sukmadinata Nana Syaodih, 2005, Landasan Psikologi Proses Pendidikan, Bandung; PT. Remaja Rosdakarya.

Naim Ngainun 2009, Menjadi Guru Inspiratif, Yogyakarta; Pustaka Pelajar.

Annurahman 2010, Belajar dan Pembelajaran, Bandung; Alfabeta.

DePorter Bobbi, 1992, Quantum Learning, New York

Penelitian sekilas, MI NU Habibul Abrori Suko Jogoyudan Lumajang, 31 Januari 2018.

Subana 2005, Statistika Pendidikan, Bandung; CV. Pustaka Setia..

Arikunto,suharsimi 2015,Penelitian Tindakan Kelas,(jakarta:Bumi Aksar)

Surapranata Sumarna 2009, Analisis, Validitas, Reabilitas dan Interpretasi Hasil Tes, Bandung; PT. Remaja Rosdakarya.

Suharsimi Arikunto 2012, Dasar-Dasar Evaluasi Pendidikan, Jakarta; PT. Bumi Aksara.

Thoha M. Chabib, 2003, Teknik Evaluasi Pendidikan, PT. Raja Grafindo Persada, Jakarta.

Sugiyono 2015, Metode penelitian pendidikan pendekatan kuantitatif,kualitatif, dan RED, Bandung; Alfabeta. 
Moh. Junaidi

82 | Bidayatuna, Vol. 01 No. 01 April 2018 